\title{
Statyba
}

\section{THE SOUND ABSORPTION OF AN ISOLATED RESONATOR WITH A CROSS-SHAPED SLIT AND ITS DEPENDENCE ON THE NUMBER OF RESONATORS}

\section{Stauskis}

To cite this article: V. Stauskis (1996) THE SOUND ABSORPTION OF AN ISOLATED RESONATOR WITH A CROSS-SHAPED SLIT AND ITS DEPENDENCE ON THE NUMBER OF RESONATORS, Statyba, 2:6, 50-58, DOI: 10.1080/13921525.1996.10531644

To link to this article: https://doi.org/10.1080/13921525.1996.10531644

Published online: 26 Jul 2012.

Submit your article to this journal $₫$

Џ Article views: 70

4 Citing articles: 2 View citing articles 진 


\section{THE SOUNI) ABSORPTION OF AN ISOLATED RESONATOR WITH A CROSS- SHAPED SIIT AND ITS DEPENDENCE ON THE NUMBER OF RESONATORS}

\section{Stauskis}

\section{Introduction}

At present, I Iclmholz type resonators are used in acoustical applications. They represent a thin slab several millimetres thick with slits or holes small in diameter. The separation between them is not large. A sound-absorbing material is always placed behind the slab. Such structure absorbs medium- and highfrequency sounds well, while absorption of low-frequency sounds is weak. 'The sound absorption qualities of this structure are mainly determined by the sound-absorbing material

Absorption of low-frequency sound is the urgent problem of architectural acoustics. Membrane structures with a large air gap behind the slab and with sound-absorbing material are used for such absorption

A resonance structure consisting of cross-shaped slits formed by four planes may represent a prospective sound-absorbing structure. These planes may be thick and rigid slabs with an air gap behind them.
The purpose of this paper is to theoretically and experimentally examine the sound absorption qualities of such structure as well as their dependence on frequency and quantity of resonators.

\section{Theory}

First of all let us consider the sound absorption qualities of an isolated cross-shaped resonator and resonator-quantity dependence of absorption. The calculation diagrams for such resonators are shown in Fig. 1.

The isolated acoustical resonator with a crossshaped slit has been theoretically examined in [1]. The main calculation formulas will be presented and the influence of the number of resonators will be theoretically assessed in this paper.

The sound absorption of such resonator will be computed from the formula

$$
A=4 \rho_{0} c_{0} \frac{\operatorname{Re} Z}{\left|Z+Z_{r}\right|^{2}} S_{r}
$$
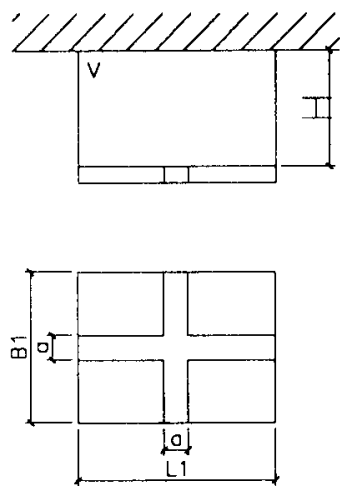

Figure 1. Calculation diagrams for an acoustical resonator with a cross-shaped slit. a) onc; b) four resonators in plan and in section.
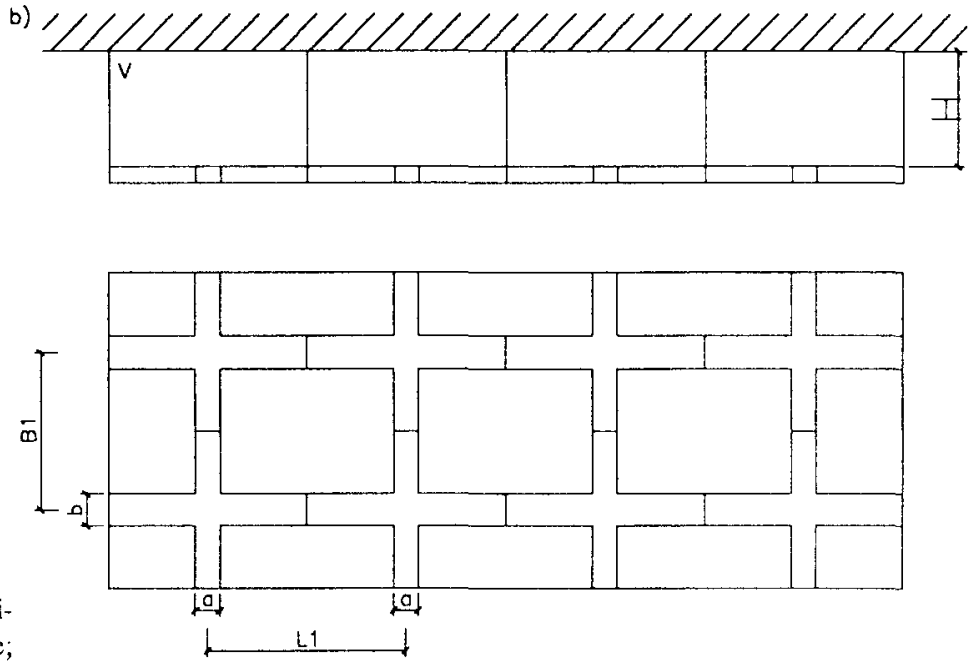
where $\rho_{0}$ is the air density; $c_{0}$ is the speed velocity in the air; $S_{r}$ is the area of the resonator; $Z_{r}$ is the resonator radiation impedance; and $Z$ is the slit impedance.

For the resonator sound absorption to be calculated, we must calculate its radiation impedance $Z_{r}$ and $Z$ its slit impedance.

The radiation impedance of the resonator will be calculated from the formula [2].

$$
Z_{r}=\rho_{0} c_{0} \frac{k^{2} S_{r}^{2}}{4 \pi^{2}} \frac{\langle v\rangle^{2}}{v_{0}^{2}} \int_{0}^{2 \pi} d \varphi \int_{0}^{\frac{\pi}{2}+j \infty}|D(\gamma, \varphi)|^{2} \sin \varphi d \varphi
$$

where $k$ is the wave number; $S_{r}$ is the resonator area; $\langle v\rangle$ is the average speed of air particle fluctuation throughout the resonator area; $v_{0}$ is the speed of a moving point for which the radiation impedance must be found; and $D$ is the radiation directivity chart for the resonator.

For the calculation of the real part of the resonator $\operatorname{Re} Z$ and the imaginary part of the resonator $\operatorname{Im} Z$, they must be singled out. Then

$$
\begin{aligned}
& \operatorname{Re} Z_{r}=\rho_{0} c_{0} \frac{k^{2} S_{r}^{2}}{4 \pi^{2}} \int_{0}^{2 \pi} d \varphi \times \\
& \times \int_{0}^{\frac{\pi}{2}} \frac{\sin ^{2}\left(k B_{1} \sin \gamma \cos \varphi\right)}{k^{2} B_{1}^{2} \sin ^{2} \gamma \cos ^{2} \varphi} \cdot \frac{\sin ^{2}\left(\frac{a}{2} \sin \gamma \sin \varphi\right)}{k^{2} \frac{a^{2}}{2} \sin ^{2} \gamma \sin ^{2} \varphi} \sin \gamma d, \\
& \operatorname{Im} Z=\frac{\rho_{0} c_{0}}{j} \frac{k^{2} S_{r}^{2}}{4 \pi^{2}} \int_{0}^{2 \pi} d \varphi x
\end{aligned}
$$$$
\times \int_{\frac{\pi}{2}-j \infty}^{\frac{\pi}{2}+j \infty \sin ^{2}\left(k B_{1} \sin \gamma \cos \varphi\right)} \frac{\sin ^{2}\left(k \frac{a}{2} \sin \gamma \sin \varphi\right)}{k^{2} B_{1}^{2} \sin ^{2} \gamma \cos ^{2} \varphi} \cdot \frac{\sin ^{2} \frac{a^{2}}{2} \sin ^{2} \gamma \sin ^{2} \varphi}{k^{2}} .
$$

Let us make a substitution: $u=\frac{\pi}{2}-j \gamma, d u=-j d \gamma$. The lower integration limit is equal to zero and the upper limit is equal to $-\infty$. Then $\cos j x=\cosh x$ and the imaginary part of the impedance will be expressed

$$
\begin{aligned}
& \operatorname{Im} Z=\frac{P_{0} c_{0}}{j} \frac{k^{2} S_{r}^{2}}{4 \pi^{2}} \int_{0}^{2 \pi} d \varphi x \\
& \times \int_{0}^{-\infty} \frac{\sin ^{2}\left(k B_{1} \cos \varphi \cosh u\right)}{k^{2} B_{l}^{2} \cos ^{2} \varphi \cosh ^{2} u} \cdot \frac{\sin ^{2}\left(k \frac{a}{2} \sin \varphi \cosh u\right)}{k^{2} \frac{a^{2}}{2} \sin ^{2} \varphi \cosh ^{2} u} \cosh u(-j d u),
\end{aligned}
$$

and
$\operatorname{Im} Z=\rho_{0} c_{0} \frac{k^{2} S_{r}^{2}}{4 \pi^{2}} \int_{0}^{2 \pi} d \varphi x$

$\times \int_{0}^{\infty} \frac{\sin ^{2}\left(k \frac{B_{1}}{2} \cos \varphi \cosh u\right)}{k^{2} \frac{B_{1}^{2}}{2} \cos ^{2} \varphi \cosh ^{2} u} \cdot \frac{\sin ^{2}\left(k \frac{a}{2} \sin \varphi \cosh u\right)}{k^{2} \frac{a^{2}}{2} \sin ^{2} \varphi \cosh ^{2} u} \cosh u d u$.

The radiation directivity chart for the crossshaped slit will be expressed as follows:

$$
D=\frac{\left(D_{1} S_{1}+D_{2} S_{2}-D_{12} S_{12}\right)}{S_{a}}
$$

where $D_{1}$ and $D_{2}$ are the directivity charts for two rectangular slits perpendicular to each other; $S_{1}$ and $S_{2}$ are the slit areas; and $D_{12}$ are the directivity chart for the overlapping part and $S_{12}$ its area, respectively.

The radiation directivity chart for the rectangular slit $D_{1}$ is calculated from the formula

$$
D_{1}=\frac{\sin \left(k \frac{B_{1}}{2} \sin \gamma \cos \varphi\right)}{k \frac{B_{1}}{2} \sin \gamma \cos \varphi} \cdot \frac{\sin \left(k \frac{a}{2} \sin \gamma \sin \varphi\right)}{k \frac{a}{2} \sin \gamma \sin \varphi}
$$

The radiation directivity chart for the rectangular slit $D$ is calculated from the formula

$$
D_{2}=\frac{\sin \left(k \frac{B_{1}}{2} \sin \gamma \sin \varphi\right)}{k \frac{B_{1}}{2} \sin \gamma \sin \varphi} \cdot \frac{\sin \left(k \frac{a}{2} \sin \gamma \cos \varphi\right)}{k \frac{a}{2} \sin \gamma \cos \varphi} .
$$

The radiation directivity chart for the overlap. ping part of two perpendicular slits is calculated from the formula:

$$
D_{12}=\frac{\sin \left(k \frac{a}{2} \sin \gamma \cos \varphi\right)}{k \frac{a}{2} \sin \gamma \cos \varphi} \cdot \frac{\sin \left(k \frac{a}{2} \sin \gamma \sin \varphi\right)}{k \frac{a}{2} \sin \gamma \sin \varphi} .
$$

The impedance of the slit itself consists of four parts and is expressed as follows:

$$
Z=Z_{m 0}+Z_{m a}+Z_{m i}+Z_{v}
$$

where $Z_{m 0}$ is the impedance of the slit itself; $Z_{m a}$ is the impedance of the added air mass outside the slit; and $Z_{m i}$ is the impedance of the added air mass inside the slit; $Z_{v}$ is volume impedance.

The impedance of the slit itself is equal to:

$$
Z_{m 0}=\frac{\rho_{0} t}{2 a} \sqrt{\frac{8 \eta}{\rho_{0}} \omega}+j \omega \rho_{0} t\left(1+\frac{1}{2 a}\right) \sqrt{\frac{8 \eta}{\rho_{0} \omega}} .
$$


The impedance of the added air mass outside the slit is equal to:

$$
Z_{m l}=\frac{\rho_{0} \Delta t_{1}}{2 a} \sqrt{\frac{8 \eta}{\rho_{0}} \omega}+j \omega \rho_{0} \frac{\Delta t_{l}}{2 a} \sqrt{\frac{8 \eta}{\rho_{0} \omega}}
$$

The impedance of the added air mass inside the slit is equal to:

$$
Z_{m a}=Z_{r}+\frac{\rho_{0} \Delta t a}{2 a} \sqrt{\frac{8 \eta}{\rho_{0}} \omega}+j \omega \rho_{0} \frac{\Delta t_{a}}{2 a} \sqrt{\frac{8 \eta}{\rho_{0} \omega}}
$$

where $Z_{r}$ is radiation impedance.

Upon inserting (12), (13) and (14) into (11), we receive the impedance of the slit itself:

$$
\begin{aligned}
& Z=\sqrt{8 \eta \rho_{0} \omega}\left[\frac{u}{4 S_{r}}\left(t+\frac{u}{\pi}\right)+\beta_{1} u\right]+ \\
& +j\left[\omega \rho_{0} t+\sqrt{8 \eta \rho_{0} \omega}\left(t+\frac{u}{\pi}\right) \frac{u}{4 S_{r}}\right]+Z_{v}
\end{aligned}
$$

where $\eta$ is the air viscosity; $u$ is the slit perimeter; $\omega$ is the angular frequency; and $Z_{v}$ is the air volume impedance obtained from the formula:

$$
Z_{v}=\rho_{0} c_{0} \frac{Z_{1} \operatorname{coth} k_{0} H+\rho_{0} c_{0}}{\rho_{0} c_{0} \operatorname{coth} k_{0} H+Z_{1}} \cdot \frac{S_{1} H}{V}
$$

where $Z_{1}$ is the ceiling impedance; and $k_{0}$ is the wave number.

For the role of the resonator number in the radiation directivity charts to be assessed, introduction of additional members is necessary. Such additional member for the rectangular slit directivity chart is expressed in the following way:

$$
\begin{aligned}
& D_{1 N}(\gamma, \varphi)= \\
& =D_{1} \frac{\sin \left[N k \frac{L_{1}}{2} \sin \gamma \sin \varphi\right]}{N \sin \left[\frac{L_{1}}{2} \sin \gamma \sin \varphi\right]} \frac{\sin \left[M \frac{B_{1}}{2} \sin \gamma \cos \varphi\right]}{M \sin \left[k-\frac{B_{1}}{2} \sin \gamma \cos \varphi\right]} .
\end{aligned}
$$

The additional member for the directivity chart is equal to:

$$
\begin{aligned}
& D_{2 N}(\gamma, \varphi)= \\
& =D_{2} \frac{\sin \left[N k \frac{L_{1}}{2} \sin \gamma \cos \varphi\right]}{N \sin \left[k \frac{L_{1}}{2} \sin \gamma \cos \varphi\right]} \frac{\sin \left[M k \frac{B_{1}}{2} \sin \gamma \sin \varphi\right]}{M \sin \left[k \frac{B_{1}}{2} \sin \gamma \sin \varphi\right]} .
\end{aligned}
$$

The additional member for the directivity chart of the overlapping part is equal to:

$$
\begin{aligned}
& D_{12 N}(\gamma, \varphi)= \\
& =D_{12} \frac{\sin \left[N k \frac{L_{1}}{2} \sin \gamma \sin \varphi\right]}{N \sin \left[k-\frac{L_{1}}{2} \sin \gamma \sin \varphi\right]} \cdot \frac{\sin \left[M k \frac{B_{1}}{2} \sin \gamma \cos \varphi\right]}{M \sin \left[k \frac{B_{1}}{2} \sin \gamma \cos \varphi\right]}
\end{aligned}
$$

where $M$ and $N$ are the number of slabs along the $X$ and $Y$ axes.

The formulas show that when the number of resonators is increased, the sound absorption is determined by the radiation directivity charts and the slit impedances which are added up.

\section{Calculation results}

In the calculations, the slab thickness is taken as $2 \mathrm{~cm}$. The resonator dimensions are taken as $2.4 \times 1.8 \mathrm{~m}$ and its depth $H$, i.e. the distance to the rigid surface is accepted as $50 \mathrm{~cm}$. The sound absorption coefficients of the rigid surface of the ceiling are assumed to be minimal: from 0.02 to 0.04 throughout the frequency range. The width of the resonator slit is taken as $30 \mathrm{~cm}$ in all cases. 100 points are taken for the calculation of each curve The angle of incidence is normal.

Figure 2 shows the dependence of the sound absorption area on the number of resonators.

The calculations show that the sound absorption is strongly dependent on the quantity of resonators. When there is only one resonator, its absorption is low and reaches 8 sq.m. at $40 \mathrm{~Hz}$. As the frequency increases, there is a uniform decrease in the absorption reaching minimal values (curve 1 ). In the case of two resonators (curve 2 ), the absorption rises to 27 sq.m., reaching its maximum at $110 \mathrm{~Hz}$. The absorption decreases along with the decrease and increase in frequency and resonance phenomena occur at high frequencies. When the number of resonators is increased to 4, 6 and 8, the sound absorption is obviously resonant with the frequency equal to $110 \mathrm{~Hz}$ approximately. The result is interesting because, along with the increase in the number of resonators, the frequency area with high sound absorption values is expanded. For instance, when the number of resonators is equal to 8 , the absorption maximum is only reached at $130 \mathrm{~Hz}$ and approaches 


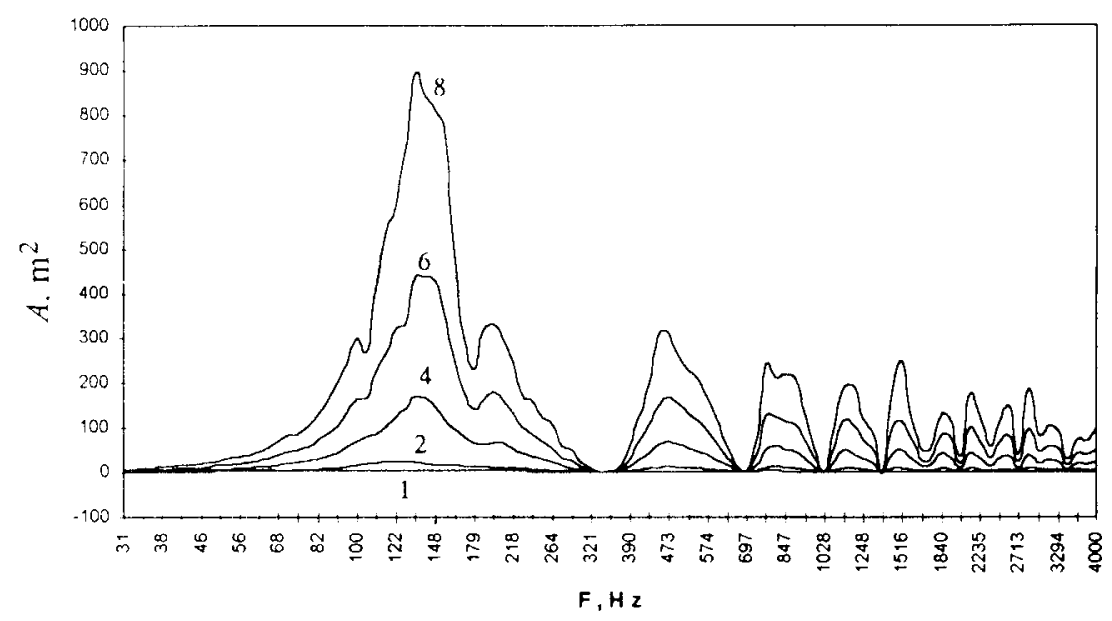

Fig. 2. The dependence of the sound absorption area of the resonators with cross-shaped slits on the number of resonators. Slit width is $50 \mathrm{~cm}$ and slit height is $50 \mathrm{~cm} .1,2,4,6$ and $8-1,2,4$, 6 and 8 resonators respectivelly

900 sq.m.; it decreases sharply when frequencies change. The absorption of 100 sq.m. occupies a frequency range of about 80 to $300 \mathrm{~Hz}$, which is wider than in the case of fewer resonators.

The changes in the real parts of the slit impedance with the increase in the resonator number are shown in Fig. 3.

The real parts of the slit impedance undergo marked changes with the increase in the number of resonators. When there is only one resonator, the real parts of the impedance uniformly increase at the frequency from $31 \mathrm{~Hz}$ to $120 \mathrm{~Hz}$, whereas at medium and high frequencies they remain almost unchanged. In the case of two resonators, the real parts of the impedance undergo spasmodic changes: they increase on frequencies up to $40 \mathrm{~Hz}$, remain unchanged in the interval up to $120 \mathrm{~Hz}$, and increase in leaps again up to $200 \mathrm{~Hz}$. There is little change after $200 \mathrm{~Hz}$. When the number of resonators is increased to 4,6 and 8 , the real parts of the impedance remain almost unchanged in the frequency range up to $150 \mathrm{~Hz}$. There is a sudden leap upwards with the increase in frequency. When the number of resonators is increased at low frequencies, the absolute values of the real parts grow smaller and are little-dependent on frequency.

In Fig. 4, the frequency-dependence of the imaginary parts of the slit impedance is demonstrated.

In this case, regularity is only observed with a small number of resonators. When there is 1 or 2 resonators, there is a very litle change in the imaginary parts of the impedance at low frequencies (about $300 \mathrm{~Hz}$ ). When the number of resonators is increased from 4 to 8 , the imaginary parts do not depend on this number and change little with the increase in frequency.

\section{Results of the experiment}

The experiment was carried out in natural conditions. The resonator with a cross-shaped slit was

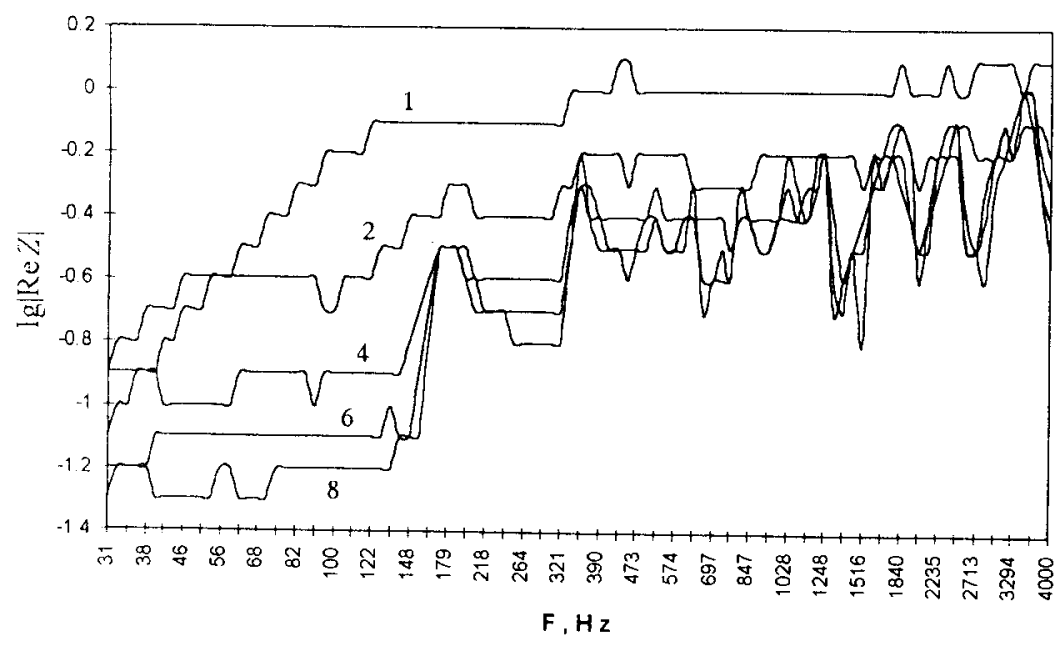

Fig. 3. The dependence of the real parts of the cross-shaped resonators on the number of resonators. 1,2 , 4,6 and $8 \cdot 1,2,4,6$ and 8 resonators respectively 


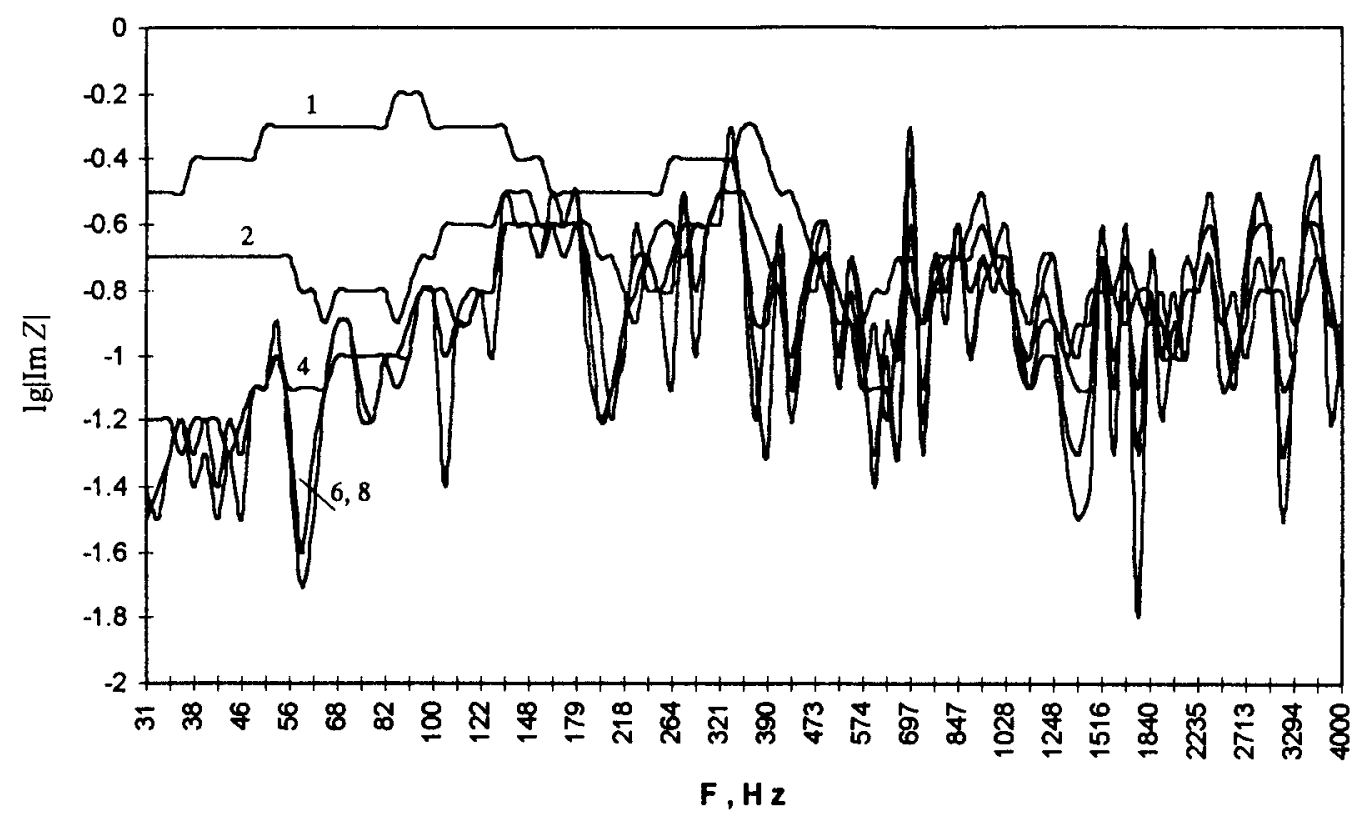

Fig. 4. The dependence of the imaginary parts of the cross-shaped resonator on the number of resonators. $1,2,4,6$ and $8-1,2,4,6$ and 8 resonators, respectively

mounted in the open air. The resonator was made of wood chipboard $18 \mathrm{~mm}$ thick. The measurements were taken in the area with no obstacles within the $20 \mathrm{~m}$. distance from the resonator. This was necessary for the elimination of the negative influence of the sound waves' reflection from the obstacles. A windless day was chosen for the experiment. The resonator was put directly on the ground which was covered with thick grass, therefore the intensity of reflections from the ground was very low.

A 9-caliber sound gun was used as sound source, i.e. the source was fully spherical. The sound source was located $1.3 \mathrm{~m}$. above the ground and $4 \mathrm{~m}$. from

o)

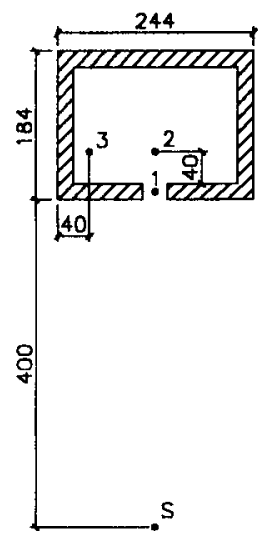

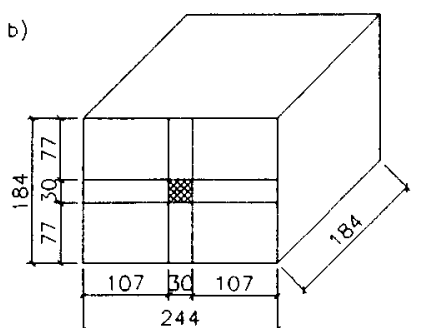

Fig. 5. The resonator with a crossshaped slit used for the experiment. S - sound source. 1, 2, 3 measurement points the resonator. Wood chipboard used for the resonator reflects sounds of all frequencies well, i.e. the sound absorption coefficients are very small and are equal to $0.02-0.04$ throughout the frequency range. Adhesive tape was used for filling the gaps between the slabs. Such conditions of the experiment enabled to assess the sound absorption qualities of the resonator itself. The diagram of the resonator under investigation is represented in Fig. 5.

Figure 6 presents the frequency-dependence of the sound absorption of the resonator at various points of measurement.

The measurements show that such resonator absorbs sound well at low frequencies, while absorption is also dependent on the point of measurement. In all cases, the maximum sound absorption is obtained at $100 \mathrm{~Hz}$ and is equal to $6 \mathrm{sq} . \mathrm{m}$. when measured at points 1 and 2 . When the measurement was taken at point 3 , the absorption was considerably smaller and was equal to $4 \mathrm{sq} . \mathrm{m}$. It is interesting to note that the maximum absorption is obtained when the measurement point 1 is located in the slit itself. These results are similar to the calculation results, with the only difference that the maximum is reached at various frequencies.

Figure 7 shows the frequency-dependence of the sound absorption coefficients. 


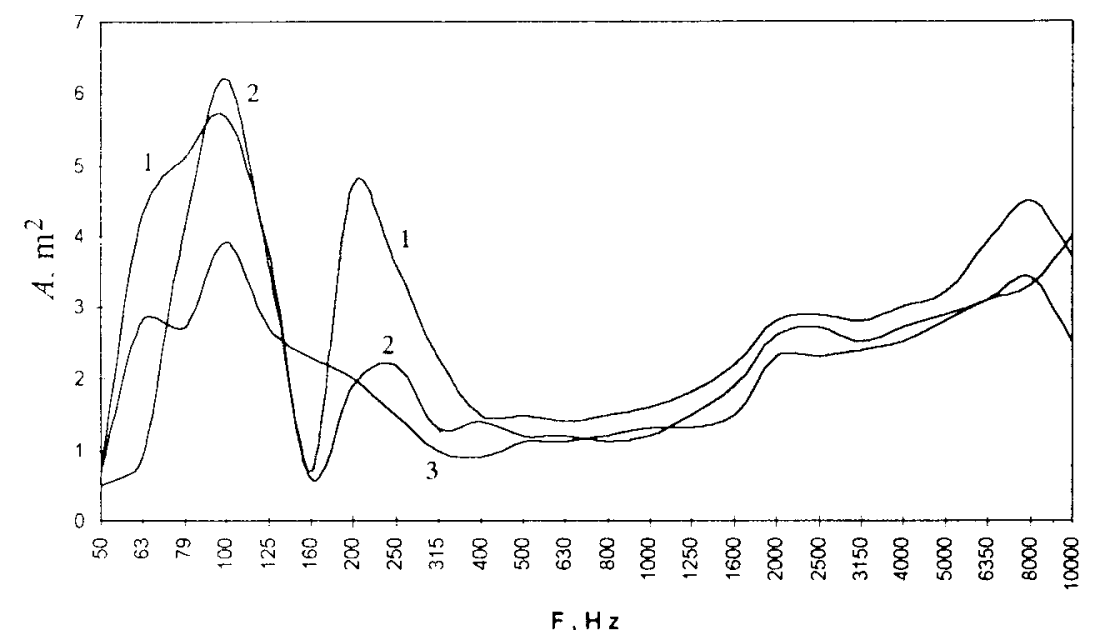

Fig. 6. The frequency-dependence of the sound absorption of the isolated resonator with a cross-shaped slit at $0-30 \mathrm{~dB} .1,2,3$ - mcasurement points
The sound absorption coefficient and the sound absorption have the same character. This is expected because the sound absorption coefficient is calculated on the basis of the reverberation time values, taking into account the areas of all surfaces. The maximum absorption coefficients are obtained at $100 \mathrm{~Hz}$. They are equal to $0.17-0.27$ and depend on the point of measurement. When the measurement point is located in the middle of the resonator slit, a considerable increase both in the absurption and the absorption coefficient is observed. Such increase is determined by the reverberation time.

Figure 8 shows the frequency-dependence of the reverberation time taking into account the muffling of the sound field at $0-30 \mathrm{~dB}$.

At point 3, the reverberation time peaks on 400 $\mathrm{Hz}$, reaching as much as $1.2 \mathrm{sec}$. At other points, this indicator is lower and is equal to $0.8-1.0 \mathrm{sec}$. at 630-800 Hz. This shows that the sound field inside the resonator is quite uneven and varies with the point of measurement. In spite of very small volume of the resonator ( 7.8 sq.m. only), the reverberation time is very long. It comes up with the reverberation time of a medium-size hall, though the hall volume is 100 and more times larger than the volume of the resonator.

The muffling of the sound field in time and by level is always varied, which is determined by the distribution of the early sound reflections over time. Figure 9 shows the change in the reverberation time, when the muffling of the sound field is approximated on the level from 0 to $-10 \mathrm{~dB}$.

The results of the examination show that the absolute values of the early reverberation time are close to the reverberation time approximated on the level from 0 to $-10 \mathrm{~dB}$. The values of this indicator at various points vary from $1 \mathrm{sec}$. to $1.35 \mathrm{sec}$. and are strongly dependent on frequency: the early re-

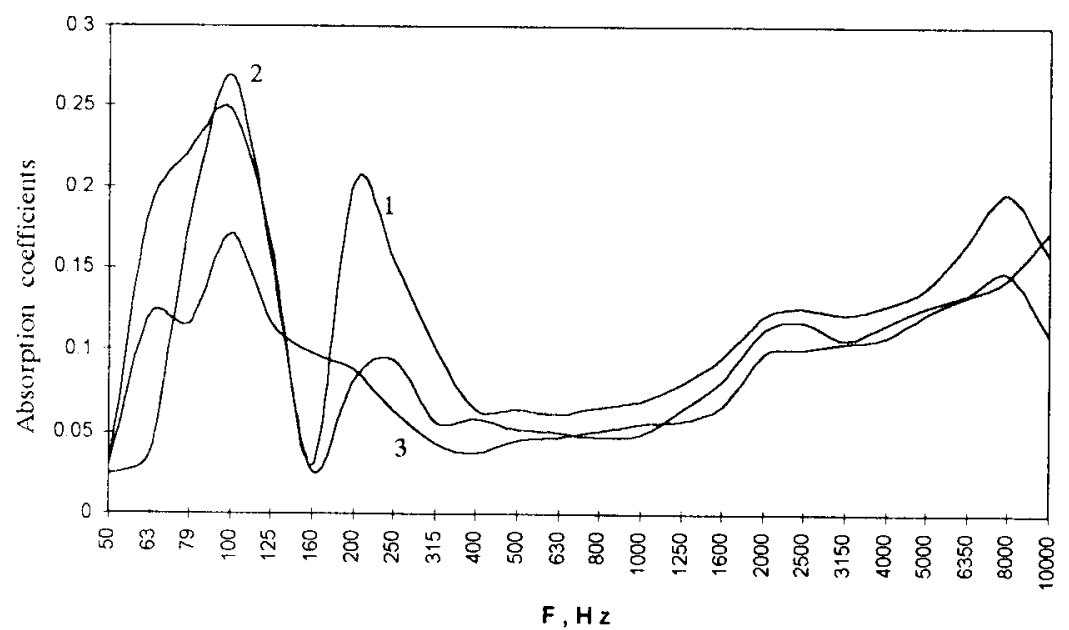

Fig. 7. The frequency-dependence of the sound absorption coefficient of an isolated resonator with a cross-shaped slit at $0-30 \mathrm{~dB} .1,2$ and 3 - measurement points 


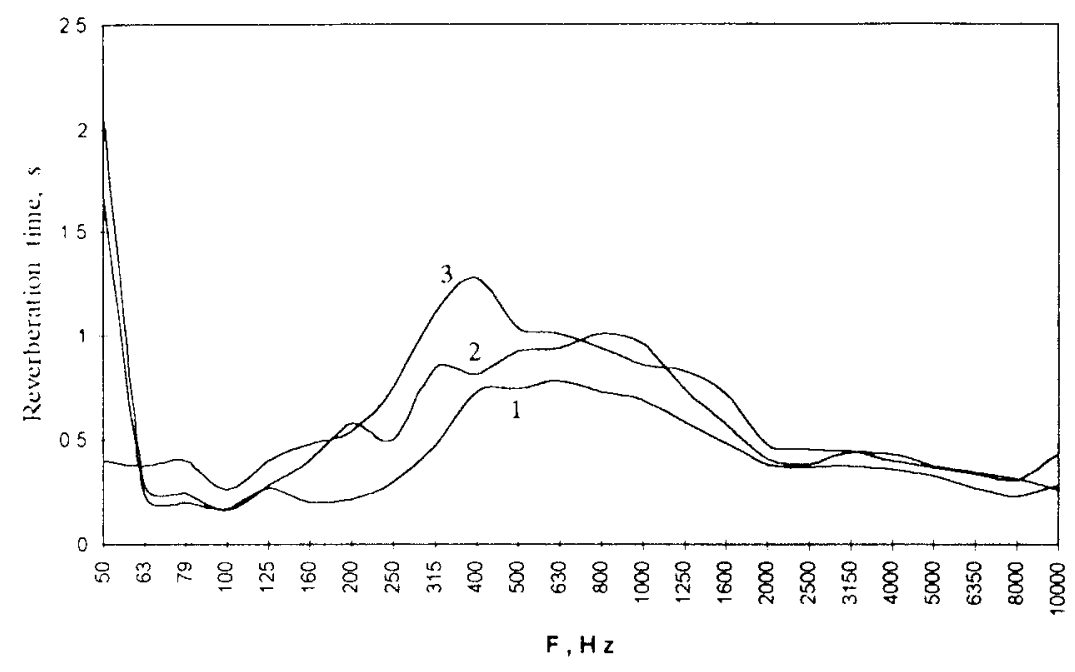

Fig. 8. The frequency-dependence of the reverberation time of an isolated resonator with a cross-shaped slit at 0-30 dB. 1, 2, 3-measurement points

verberation time is very short at low and medium frequencies up to $250 \mathrm{~Hz}$. Depending on the point of measurement, this time peaks at 400,630 and $800 \mathrm{~Hz}$ and then rapidly decreases along with the increase in frequency. We see that the values of this indicator change cvery $0.2 \mathrm{sec}$. along with the change in frequency, which is very much.

The early reverberation time correlates with the acoustical centre of gravity well. Figure 10 shows the frequency-dependence of the acoustical centre of gravity at various points of measurement.

The results of the examination show that the acoustical centre of gravity, when measured in the slit of the resonator (point 1), is little-dependent on frequency and varies over the interval of $10-20 \mathrm{~ms}$. When the points of measurement are inside the resonator (points 2 and 3), the acoustical centre of gravity has its marked maximums at $800 \mathrm{~Hz}$ and 400 $\mathrm{Hz}$. This shows that the sound energy is concentrated in the medium-frequency range.

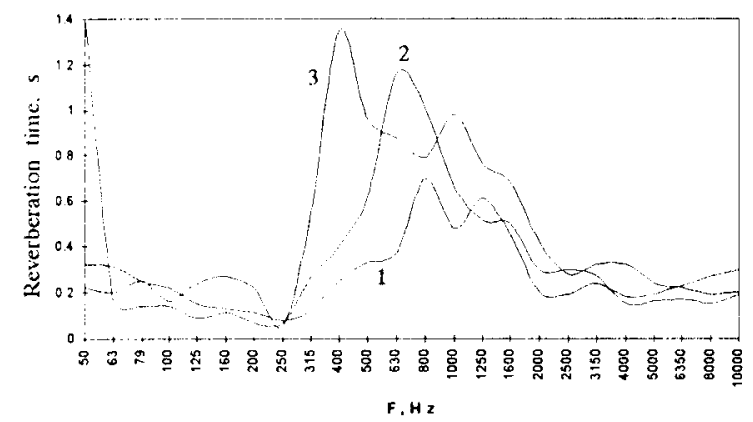

Fig. 9. The frequency-dependence of the reverberation time of a resonator with a cross-shaped slit at $0-10 \mathrm{~dB} .1,2$, 3 - measurement points.
The distribution of the sound energy is wellcharacterized by the relationship between the direct sound energy and the reflection energy $\beta /$. The results of examinations are presented in Fig. 11.

When determining the energy relationship, the direct sound energy was taken as lasting $5 \mathrm{~ms}$. When the measuring microphone is in the slit (point 1 ), the reflection energy prevails in the frequency range up to $400 \mathrm{~Hz}$. In the frequency range of $400-10000$ $\mathrm{Hz}$, however, an inverse phenomenon is observed: the direct sound and some early reflections are more energetic. When the point of measurement is inside the resonator (point 2), we have a balance between the direct sound energy and the reflected sound energy almost throughout the frequency range. Similar result is obtained in the case when the point of measurement (point 3 ) is inside the resonator, near its edge (curve 3 ). These results are demonstrative of the fact that the formation of acoustical indicators is greatly influenced by the direct sound.

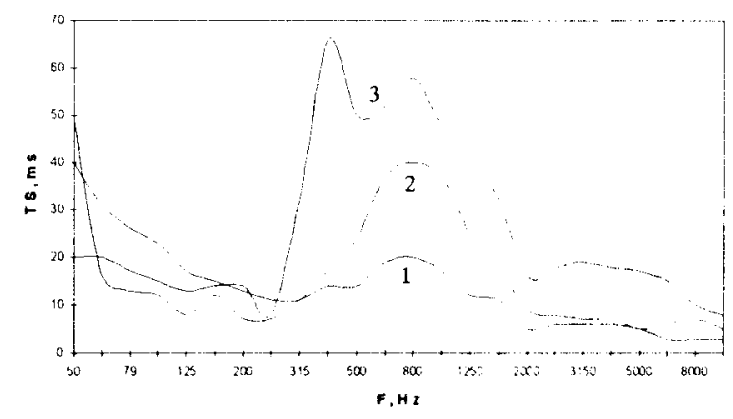

Fig. 10. The frequency-dependence of the acoustical centre of gravity of the resonator with a cross-shaped slit. 1, 2, 3 - measurement points 


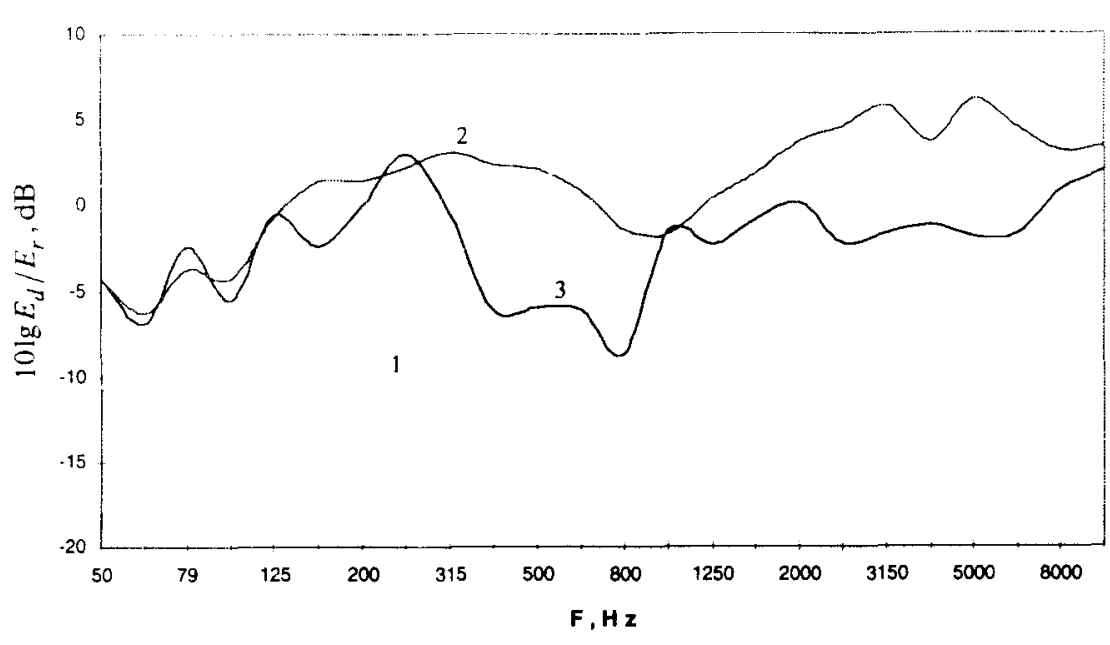

Fig. 11. The frequency-dependence of the sound energy rclationship in the resonator with a cross-shaped slit. 1, 2, 3 - measurement points

\section{Conclusions}

1. The calculations show that the sound absorption of the resonator with a cross-shaped slit is strongly dependent on the number of resonators. As the number of resonators is increased, the sound absorption maximum is almost independent on frequency, whereas the absorption area is enlarged.

2. The real part of the slit impedance is dependent on the number of resonators at low frequencies only.

3. The imaginary part of the slit impedance is littledependent on the number of resonators and on frequency.

4. The results of the experiment show that the maximum sound absorption of one resonator is obtained at $100 \mathrm{~Hz}$ and reaches 4-6 sq.m. depending on the point of measurement. The findings are similar to the results of calculation, with the only difference in frequency at which the maximum is achieved.

5. The sound absorption coefficients have their maximum of $0.17-0.27$ at $100 \mathrm{~Hz}$ and vary from one point of measurement to another.

6. The reverberation time of the resonator peaks in the frequency range of $400-800 \mathrm{~Hz}$, reaching as much as $0.8-1.2 \mathrm{sec}$.

7. The acoustical centre of gravity is concentrated in the frequency range of $400-800 \mathrm{~Hz}$. The direct sound is of considerable importance in the energy distribution.

\section{References}

1. V. Stauskis. Sound absoption qualities of a crossshaped isolated acoustic rezonator // ACUSTICA - acta akustica. Vol. 82, 1996. Suppl. 1, p. 141.

2. C. Skudrzyk. The foundation of acoustics. V. 2. Springer-Verlag, Wien, New York: 1971. 436 p.

3. V. Stauskis. The near and far acoustic field and its relationship to the hall // STATYBA, 1996, No 2(6). Vilnius: Technika, 1996, p. 59-67.

Iteikta 19960505

\section{VIENETINIO AKUSTINIO REZONATORIAUS SU KRYŽIAUS FORMOS PLYŠIU ABSORBCIJA IR JOS PRIKLAUSOMYBÉ NUO REZONATORIU KIEKIO}

\section{Stauskis}

\section{Santrauka}

Teoriškai nagrinèjama vienetinio, didelių matmenų akustinio rezonatoriaus su kryžiaus formos plyšiu garso absorbcijos, plyšio impedanso realių ir menamy daliu priklausomybe nuo rezonatoriu kiekio. Skaičiavimais nustatyta, kad garso absorbcija priklauso nuo rezonatoriụ kiekio. Vienas rezonatorius, kurio plotas $4,3 \mathrm{~m}^{2}$, o plyšio plotis $50 \mathrm{~cm}$ esant $125 \mathrm{~Hz}$ absorbuoja apie $5 \mathrm{~m}^{2}$ garso energijos. Kai rezonatorių skaičius padidèja iki 2, absorbcija siekia $27 \mathrm{~m}^{2}$. Didejjant rezonatorių skaičiui iki 4,6 ir 8 , garso absorbcijos plotas atitinkamai padideja iki 180, 400 ir $900 \mathrm{~m}^{2}$. Didejant rezonatoriu skaičiui, plateja dažniu sritis, kurioje garso absorbcija turi dideles reikšmes.

Plyšio impedanso realios dalys, didejant rezonatoriy skaičiui mažèja ir jos auga didejant dažniui. Tai ypač ryšku esant žemiems dažniams. Plyšio impedanso menamos dalys, didejjant rezonatorių skaičiui, mažai priklauso nuo dažnio ir esant žemiems dažniams jos mažeja, didejant rezonatorių skaičiui. 
liksperimentiniai tokio re\%onatoriaus tyrimai rodo, kad maksimali jo absorbcija csant $100 \mathrm{~Hz}$ sickia $4-6 \mathrm{~m}^{2}$, ir tai priklauso nuo matavimo taško. loks rezonatorius, kurio tūris yra tik $7.8 \mathrm{~m}^{3}$, turi dideli reverberacijos laiką. Matuojant pagal lygi $0-30 \mathrm{~dB}$, jo maksimalios reikšmes dizznily diapazonc 400 - $800 \mathrm{~Hz}$ sickia $0.8-1.2 \mathrm{~s}$. Ankstyvas reverberacijos laikas sickia $1-1,4$ sekundes ir turi ryšku maksimumạ csant vidutiniams dažniams. Šis rodiklis taip pat priklauso nuo matavimo taško.

Akustinio svorio centro reikšmès sickia maksimumo esant vidutiniams dažniams. Jo reikšmes šiame diapazone yra z̆miai didesnes negu esant žcmiems ir aukštiems dažniams. Sis rodiklis gerai korcliuoja su ankstyvuoju reverheracijos laiku.

(iarso absorbcijos koeficiento kitimo charakteris yra toks pat. kaip ir garso absorbcijos. Jo maksimalias reikšmes gauname esant $100 \mathrm{H} \%$, jos sickia $0,17-0,27$ ir priklauso taip pat nuo matavimo taško. Tai rodo, kad vienetinis rezonatorius su kry̌izaus formos plyšiu gerai absorbuoja garso inergija csant ð̌micms dažniams ir kad garso laukas re\%onatoriuje yra netolygus. loks rezonatorius ne tik gerai absorbuoja garso energiją, bet ir didelę jos dali grą̆ðina atgal i aplinką. Toks akustinis reiškinys gali padèti korcguojant jau pastatytos salés akustiką, tam visai nenaudojant garsạ absorbuojančiu medžiagu.

Vytautas STAUSKIS. Doctor, Associate Professor. Department of Building Structures. Vilnius Technical University, 11 Saulètekio Ave, LT-2054 Vilnius, Lithuania. In 1974 a thesis in technical science. From 1974 at VTU Department of Building Structures as assistant, Master of science. Scientific visits: Moscow Civil Engineering Institute, Sankt-Peterburg Politechnical Institute. Research intercsts: experimental testing of halls by primary hall models and on site, computer simulation of theoretic tasks, wave diffraction and reflections, direct sound and subjective acoustic indicators, large-dimension resonance structures, carly attenuation of acoustic field and its relation to hall acoustics. 